\title{
Interfaith Figures Communication Model in Building Religious Harmony in North Labuhanbatu Regency
}

\author{
Syukur Kholil ${ }^{1}$, Yusnadi², Ibrahim Sihombing ${ }^{3}$ \\ 1,2,3 Universitas Islam Negeri Sumatera Utara, Indonesia \\ sihombing078@gmail.com
}

\begin{abstract}
This study about Interfaith Figures Communication Model in Building Religious Harmony in North Labuhanbatu Regency deals with the awareness of interfaith leaders in Labura of the importance of living harmoniously between religious communities, it is important for them to disseminate their understanding of how to build harmony and harmony between religious communities at the root of the clump (community). Therefore, religious figures "berkampenye" to the community about the importance of building a harmonious and harmonious life among communities adhering to different religions in Labura. Research that researchers do is field research (Field Research) which is included in the type of qualitative descriptive research, therefore, in the data collection process, researchers will make field observations behavior in Paud Al Ummah delitua. Thus the creation of dialogue (communication) between religious leaders has rational reasons behind it, including such as the existence of religious plurality in society, the desire to communicate in an effort to understand each other, and the creation of cooperation in society.
\end{abstract}

Keywords

communication mode; interfaith figures, religious harmony

\section{Introduction}

In Indonesia, the spirit of religious tolerance has long been established, with the introduction of the slogan of diversity since time immemorial. Tolerance is not only a social reality but also an idea, understanding, and ideas for the sake of an independent country. The uniting of components with different backgrounds as a form of resistance against colonialism, in order to seize independence as proof that this country was not born based on only one religious group, but a mutual agreement from each religious group.

The 1945 Constitution as the constitution also states clearly that, "the state guarantees the freedom of every citizen to embrace his or her own religion and to worship according to his religion and belief". Under this law, all citizens, with various cultural identities, ethnicities, genders, religions and so on, must be protected by the state. This also means that the state must not discriminate against its citizens for any reason. The government and all citizens are obliged to uphold the Constitution. With this diversity, it is hoped that humans can take lessons from creation through the potential of reason, which can then be used as capital for the development of a more useful life.

The thing that needs to be considered the most at this time, especially in Indonesia is our concern that we will understand the values of these differences, the fanaticism carried out by several groups is sometimes not placed according to the place or conditions, which causes recently there have been frequent clashes between religious groups in Indonesia. As citizens who are born from the slogan "Bhineka Tunggal Ika", they should instill that the value of difference is not a problem, but that the difference is a gift given by the creator. 
Because after all the countries located in parts of the world, there are hardly any followers or followers of a uniform religion. Adults face differences for the common good.

The existence of ethnic differences in society is more due to the process of separation and unification so that differences can be maintained in the course of one's life (Hisarma Saragih, Subhilhar, Hamdani Harahap \& Amir Purba, 2019) A plural society can be understood as a way of seeing society about the meaning of plural society, for example the behavior of respecting cultural and religious diversity and maintaining the values of tolerance in society. In this condition, society is required to realize awareness of humans primarily as a social society. That is, humans live side by side in peace and harmony amidst diversity. Facts on the ground show that the people of North Labuhanbatu are a plural society with various beliefs. According to the Social Psychology in Sugiharto (2020) a class is a mirror of society at large and has a function as a laboratory of learning in real life.

\section{Review of Literature}

\subsection{Interpersonal Communication Theory}

Communication can be termed an effort to build togetherness between two or more people. According to Deddy Mulyana, the word communication is a process in delivering information, both ideas, ideas aimed at other people to answer a question that is conveyed. According to Lasswell, communication consists of several elements, communication isdthe communicatordform messagesdand deliver it dthrough adcertain channeldto the partiesdrecipient who raisesdcertain effect.

1. Who (Communicator), namely someone who provides information to other people who are considered to be recipients of information that is done consciously or deliberately.

2. Says What (Message), an information provider must convey the information obtained to someone who is entitled to receive the information. the message can be direct or indirect (verbal / non-verbal).

3. In Which Channel (Media used). The point is that in conveying information, a message provider can use communication media which can be used as a medium to convey information. Because the media is a means of conveying information that can be used by a message giver.

4. To Whom (Communicant). This means someone who receives a message or information from the communicator.

5. With What Effect (Effect). In this case the intention is a response in a communication.

\subsection{Barriers to Communication}

In communication, when delivering messages from the communicator to the communicant, the understanding often occurs as desired. In fact, misunderstandings arise. The message cannot be received perfectly due to differences in the symbol or language used with the language received. There are other technical obstacles that lead to the idea of a smooth communication system for both parties. Kreitner in Ruslan explains four kinds of obstacles that can disrupt the communication system, namely:

a. Barriers in the delivery process

This obstacle comes from the communicator (sender barrier) who has difficulty in delivering messages, does not master messages, and does not yet have the ability to be a reliable communicator. This barrier also comes from the receiver of the message (receiver barrier) because of the difficulty of the communicant in understanding the message well. This can be caused by the low level of mastery of language, education, intellectuality, and so on in the communicant. Communication failure can occur due to factors, feed-back 
(results not achieved), medium barrier (media or tools used inappropriately) and decoding barriers (barriers to understanding the message correctly).

b. Physical Barriers

Physical means can hinder effective communication. For example, hearing is less sharp and interference with the system or interference with the loudspeaker (sound system) which often occurs in a lecture / seminar / meeting room, and others. Things that can make the messages ineffective get to the communicant.

c. Simantic Barriers

The semantic barrier (language or the meaning of the word) is the difference in understanding between the message giver and the receiver about one language or symbol. It is possible that the language conveyed is too technical or formal, making it difficult for communicants whose level of knowledge and understanding of technical language is lacking. Or vice versa, the level of knowledge and technical language of the communicator is less.

d. Psycho-social barrier (psychosocial barrier)

There are wide differences in the aspects of culture, customs, habits, perceptions and values so that the tendencies, needs and expectations of the two communicating parties are also different. For example, the communicator (speaker) conveys the word "specter" which is correct in Indonesian. In fact, the word in Sundanese means not good.

\subsection{Interreligious Communication in Indonesia}

Human life throughout history has always needed religion. It is almost certain that all individuals in society have a religion which is used as a way of life. Religion becomes a guide for humans to live and live on top of the world. Therefore, religion has a close relationship with all the factors that make up the social structure of society, such as political institutions, customs, economy, family, education, and others. As a consequence of the statement that religion is a way of life, religious adherents must be able to make religion a buffering factor to achieve inter-religious harmony. The awareness to build religious harmony is part of the awareness that humans are created in the concept of pluralism

\section{Research Methods}

Research that researchers do is field research (Field Research) which is included in the type of qualitative descriptive research, therefore, in the data collection process, researchers will make field observations. Qualitative research is a research that is used to reveal problems in the work life of government, private, community, youth, women, sports, arts and culture organizations so that it can be used as a policy to be implemented for the common welfare. According to Sugiyono, "Problems in qualitative research are temporary, tentative and will develop or change after the researcher is in the field."

\section{Discussion}

One thing that cannot be denied is that human life on this earth is not single, especially when we look at it from a religious aspect. Religious plurality is present in the space of human life, including in the religious life of the Labura community. As illustrated in the population statistics based on religion, the reality of the pluralistic religious life of the Labura community must become the foundation in shaping the development component in Labura. Therefore, it is necessary to have a conducive and stable atmosphere based on a spirit of tolerance in order to create an atmosphere of harmony between religious communities. 
On the basis of the pluralism of the pluralistic religious life of the Labura community in the aspect of religion, it has encouraged religious figures to build a communication between interfaith figures to jointly build a spirit of harmony between religious communities in Labura. As stated by the following informant:

"Before FKUB existed, there were meetings between religious figures but not formal. Only meetings to meet where, I see. The meeting was only an initiative of called religious figures, to build communication."

Based on the above interview, it seems that the communication that occurs between interfaith figures is a model of non-formal communication. Even though the communication that occurs is non-formal, these meetings aim to create a togetherness by two or more people that causes interactions to regulate the environment by building relationships between people through the exchange of information in strengthening one's attitudes and views.

The awareness of interfaith figures in Labura towards the reality of the pluralistic Labura society, especially in the religious dimension, has encouraged them to take the initiative to build communication between other religious figures so that there will be no clashes in the plural society. Awareness of the religious plurality (plurality) of the Labura community has encouraged religious leaders to build communication aimed at finding a common ground for religions, so that different religions can coexist within the framework of harmony between religious communities. This is as stated by Ringgo-ringgo, namely:

"Actually, the main thing is the awareness of the religious leaders. Those religious figures, right, realize that we cannot be one in religious matters. So FKUB is a bridge where we can meet. The differences remain, but where we have similarities, that's where we meet. That's why [there is a motto] 'harmony is established, aqidah is guaranteed'. Then the role of the regional government does exist, but what is bigger is the awareness of the religious leaders themselves. In Labura, I think the roles of religious figures are quite good. So with the awareness of religious leaders, the government pushes it, if it intervenes, don't ".

Through time, societies have been transformed from small associations of individuals tied together by instincts, need, and fear, to small communities tied together by circumstances, kinship, traditions, and religious beliefs, to nations tied together by history, politics, ideology, culture, and laws (Nurwani et al, 2020). The communication that occurs between religious leaders has encouraged religious social interaction. Awareness of the importance of living in harmony between religious adherents is the main spirit for religious leaders to carry out dialogue in order to find religious common ground in realizing religious harmony. It must be admitted that awareness of plurality which becomes a reality in society is a challenge for religion (religious leaders) and society in general. This is where the importance of finding a meeting point (convergence) of religions.

There are several considerations as an important frame of reference in the search for a meeting point of religions, namely: first, practically the dimensions of religious pluralism in society have not been fully understood by religious communities, so what emerges is an attitude of exclusivity in religion. At a certain point, the exclusive attitude of returning to religion creates an attitude of blaming other people's religious teachings. So that it raises an attitude of religious arrogance which in the end can lead to conflict in the name of religion. Second, in the midst of religious plurality, someone with an exclusive religious attitude will tend to monopolize religious diversity and monopolize the truth of salvation. In fact, sociologically, this can lead to conflict between religious groups. It must be admitted that non-formal meetings to build communication between religious leaders are still a model of interpersonal communication. Theoretically, this interpersonal communication is carried out by parties that take place face to face or through communication media, such as using 
the telephone other media. This communication generally occurs between two people involved, such as husband-wife communication, two colleagues, teacher-students and so on.

In the context of this interpersonal communication, the non-formal communication that occurs between religious figures in Labura does not involve all religious figures in it. This means that only two religious figures met to build communication related to efforts to build harmony in Labura. With this kind of communication model, the intensity and continuity of communication between religious figures tends to be rare. This is as expressed by almunir, an Islamic religious leader in Labura:

"Before FKUB was formed we realized the need for harmony. Sometimes we from one religion to another, the religious figures are suspicious of each other. Because there is no communication. There are many issues that cannot be resolved due to lack of communication with one another."

The same thing was also expressed by Gunawan, a Buddhist leader:

"Before FKUB existed, we rarely felt the communication between Buddhists and people of other religions. If there is, yes, just occasionally. For example, I met one of the other religious figures, where is that? Even then, you could say it's rare."

Based on the cut from the interview with the informant above, communication between interfaith leaders in Labura has taken place between them. This non-formal interpersonal communication is an initiative of religious leaders who have (called) to voice the importance of tolerance in Labura on the basis of the pluralism of the pluralistic religious life of the Labura community in the religious aspect.

In general, this interpersonal communication occurs because of closeness, or friendship that has the same goal. The closeness of the relationship between the communicating parties will be reflected in the types of messages or their nonverbal responses, such as touch, expressive gaze, and very close physical distance. Although everyone in interpersonal communication is free to change the topic of conversation, in reality interpersonal communication can be dominated by one party.Dean Barnulus in Liliweri, that interpersonal communication is associated with meeting several individuals suddenly or spontaneously, without being scheduled to discuss an agenda. It is further explained by Redding, in Muhammad, that in developing / advancing an interpersonal communication into a social interaction. This social interaction is generally formed from communication about social things. In this context, interfaith figures in Labura met and discussed socio-religious issues, particularly those related to building harmonious relations between religious communities within the framework of harmony.

It must be admitted that the frequency of religious leaders in building communication is still relatively small. This is because the communication that is built is the initiative of several religious leaders themselves. communication through non-formal meetings. In that meeting generally only involved two people from two different religions. This is as expressed by Ringgo-ringgo, a Christian religious leader in Labura;

"Before FKUB existed, the meeting was there but very small. That too is incidental in nature. When there is a problem, well, the government just takes action. For these informal meetings, they are initiated individually."

Based on the interview excerpt above, it can be seen that the spirit to build communication among interfaith figures aims to foster a spirit of harmony created through the initiation of religious leaders in Labura. In this context, religious leaders as religious authorities are "agents" who emphasize the importance of building harmony. Agents (religious leaders) have the ability to build communication between interfaith figures. Religious leaders as agents have the power to hold meetings to build communication without being attached to other institutions. 
In communicative action theory, the things that underlie the interaction are based on rational-practical moral ethics, where categories are imperative with normative-universal claims. This theory of communicative action describes the structure of moral decisions expressed through the theory of social psychology of morals and links them to social interaction through procedures of moral argumentation in an effort to understand each other through rational agreement.Agency theory, as explained by Giddens, is based on the concept of "structural duality in the relationship between agent and structure, that structure is a medium as well as a result of actions that are organized in a sustainable manner. Agents, in this case religious figures, are real people in the continuous flow of actions and events. Whereas structure is the rules and resources formed from and forming repetition of social practices, in this case communication is to build harmony.

Through communication carried out by agents based on their initiative, this activity aims to transform the social structure or create an ideal social structure, in this case the maintenance of inter-religious harmony in Labura. The communication that occurs between interfaith figures is a form of communication from the "experience of faith". If the experience of faith is understood as the basis for communicative action, it will form communicative action with followers of other faiths (religions), which in this context is the dialogue of religious communities. Because in essence the experience of faith is the culmination of religious appreciation in the life of the human person.

Through non-formal interpersonal communication carried out by interfaith figures in Labura, whether we realize it or not, they have learned from one another about something about the other party. In addition, this interpersonal communication, interfaith figures understand each other or know themselves and discover the "outside world" about other people, attitudes and behavior will be formed related to maintaining the harmony of religious relationships. On that basis at some point forming and maintaining meaningful relationships, which in this case is the importance of a harmonious and harmonious life between religious communities in Labura.

The access of religious leaders to religious institutions is the main leading sector in maintaining these institutions as transformative media. The agent of change was initially placed outside human beings and outside the life of society, which was more specifically placed on supernatural powers. In subsequent developments, agents of change are placed within "great humans" such as prophets, heroes, heroes, leaders, commanders, inventors, creators, human geniuses and so on. They are the movers of society, but their charismatic capacities do not come from society. This capacity is believed to be from birth, genetically inherited and individually developed. In this phase, agents of change begin to be humanized, but they are not yet socialized. With the birth of sociology, a very surprising event occurred, namely the agents of change began to be socialized and even had a social role.

\section{Conclusion}

With the awareness of interfaith leaders in Labura of the importance of living harmoniously between religious communities, it is important for them to disseminate their understanding of how to build harmony and harmony between religious communities at the root of the clump (community). Therefore, religious figures "berkampenye" to the community about the importance of building a harmonious and harmonious life among communities adhering to different religions in Labura. Thus the creation of dialogue (communication) between religious leaders has rational reasons behind it, including such as the existence of religious plurality in society, the desire to communicate in an effort to understand each other, and the creation of cooperation in society. 
Dynamic religious life is a basic factor that is decisive for the realization of pluralism awareness to build harmony between religious communities. Dynamic religious life is reflected in good, authentic, and productive religious harmonywith mature religious persons with an automatic, critical and open moral attitude. Not shutting down from different parties, building dialogues, non-exclusive religious views and attitudes are opportunities for the creation of harmonious and harmonious religious life in society.

Therefore, interpersonal communication plays an important role at any time, as long as humans still have emotions. In fact this face-to-face communication makes humans feel more familiar with each other. Through interpersonal communication it encourages the realization of social interaction, so that common goals can be achieved.

\section{References}

Ahmad Fedyani Saifuddin. (1986). Konflik dan Integrasi, Perbedaan Faham dalam Islam, Jakarta: Raja wali.

Bungin, Burhan. (2006). Sosiologi Komunikasi: Teori, Paradigma, dan Diskursus Teknologi Komunikasi di Masyarakat. Jakarta: Kencana.

Clifford Geertz. (1960). The Religion of Java, Berkeley; The Free Press.

Coward. (1989). Pluralisme dan Tantangan Agama-agama, Yogyakarta: Kanisius.

D. Mulyana. (2005). Komunikasi Efektif suatu Pendekatan Lintas Budaya, Bandung: Remaja Rosdakarya.

Depag RI. (1997). Bingkai Teologi Kerukunan Hidup Umat Beragama Di Indonesia, Jakarta: Badan Penelitian dan Pengembangan Agama Proyek Peningkatan Kerukunan Umat Beragama di Indonesia.

Departemen Agama RI. (1989). Al Qur'an dan Terjemahnya, CV.Toha Putra, Semarang.

HB. Sutopo. (2006). Metode Penelitian Kualitatif, Surakarta: UNS Press.

Hisarma Saragih, Subhilhar, Hamdani Harahap \& Amir Purba (2019) The struggle of Batak Simalungun for their identity in Church organization in Simalungun, Medan, Indonesia, Journal of Human Behavior in the Social Environment, 29:6, 693-704, DOI:10.1080/10911359.2019.1590888

Imam Syaukani. (2008). Kompilasi Kebijakan Dan Peraturan Perundang-Undangan Kerukunan Umat Beragama, Jakarta, Puslitbang.

J. Peacock. (1978). The Muhammadiyah Movement in Indonesia Islam: Purifying The Faith, California: The Bunyamin/ Coming Publishing Company, 1978

Kuntowijoyo. (2001). Muslim Tanpa Masjid, Bandung: Penerbit Mizan.

Liliweri, Alo. (1991). Komunikasi Antarpribadi. Bandung : Citra Aditya Bakti.

Martin Van Bruinessen. (1995). Kitab Kuning, Pesantren dan Tarekat, Bandung: Mizan.

Nurwani, N., et al. (2020). The Creativity of Society Making Ritual Becomes Show Art: Transformation of Ratok Bawak Meaning on Minangkabau Society, Indonesia. Creativity Studies, 437-448.

Sugiharto (2020) Geographical students' learning outcomes on basic political science by using cooperative learning model with Group Investigation (GI) type in State University of Medan, Indonesia, Journal of Human Behavior in the Social Environment, 30:4, 447-456, DOI: 10.1080/10911359.2019.1696261

Turner, Jonathan H. (1975). The Structure of Sociological Theory. Illiois: The Dorsey Pers.

Wolf, Ruth A Wallace dan Alison. (1995). Contemporary Sociological Theory Continuing the Classical Tradition. New Jersey: Englewood Cliffs.

Z, Arifin. (2010). Teori Keuangan dan Pasar Modal. Jakarta: Sinar Grafika. 